\title{
Adoption of educational technology ten years after setting strategic goals: A Canadian university case
}

\author{
George Zhou \\ University of Windsor, Canada \\ Judy $\mathrm{Xu}$ \\ University of Alberta, Canada
}

Through surveys, focus groups and interviews, this study examines technology adoption at a large Canadian university ten years after setting a strategic plan, explores the interplay between instructors' concepts of teaching and use of technology, and searches for the best solutions to help them use technology more effectively. Results showed that whilst $90 \%$ of respondents were using computers in teaching, there is still much to do in helping them to increase the effectiveness of their use of technology. While the university reward system needs to offer better recognition of the scholarship of using computers, rationales for technology adoption and successful cases demonstrating the effectiveness of technology integration are essential to encourage and improve the use of computers. Professional development needs to move beyond technical workshops to include pedagogy oriented mentorship amongst practitioners.

\section{Introduction}

Computer based educational technology has the potential to improve teaching practices in higher education; however, it is not easily integrated into the teaching system. Studies have indicated that there exist numerous barriers against university instructors adopting educational technology (Adams, 2003; Cuban, 2001; Ebersole \& Vorndam, 2003; Groves \& Zemel, 2000; Jacobsen, 1998; Reeves, 2003), and more studies are necessary to help develop solutions.

This study was conducted at the University of Alberta, a large, prestigious university located in western Canada and enrolling over 35,000 students. In its vision statement, the university aims to "become indisputably recognised, nationally and internationally, as one of Canadian's finest 
universities." The mission of the university is stated to "serve our community by the discovery, dissemination and application of new knowledge through teaching and research." About ten years ago, the University of Alberta adopted a strategic plan that stressed the important role of e-learning in meeting its vision and mission. This plan defined elearning as teaching and learning through information and communications technologies that may include, but are not limited to, the following: presentation technologies (e.g. PowerPoint), the Internet, video conferencing, email, disciplinary software, leaning management systems (e.g. WebCT), simulations, and educational games. It believes that elearning has direct relationship with two major university academic themes, namely improving the quality of undergraduate experience and focusing on the teaching and research continuum. E-learning offers possibilities for active teaching and learning processes despite large class sizes, increased access to teaching and research information, and facilitating collaboration with local and remote instructors and researchers. The strategic plan explicitly stated the importance of support to help instructors use technology. During the past ten years, several organisational units including the e-learning group at the Computing and Network Services, Academic Technologies for Learning at the Faculty of Extension, and Arts Resource Center at the Faculty of Arts, were set up to promote the use of technology by providing technical support, professional development workshops, and instructional design services.

According to the needs assessment conducted by the university at the time when the strategic plan was formed, approximately $15 \%$ of its instructors had started using computers in teaching (Anderson, Varnhagen, \& Campbell, 1998). This study is considered as a follow up. It explores answers to the following questions: How are instructors using computer technology in teaching? What challenges do they still have in adopting computer technology? What are the best solutions to help them use computer technology effectively? Through this examination of instructors' current use and needs in technology, we expect to gain insights regarding the best solutions for professional development in technology adoption, which was set as the central purpose of this study.

\section{Literature review and research context}

\section{Adoption of technology}

Past studies have indicated three types of factors influencing the adoption of technology at universities: technical factors, individual factors, and organisational factors. Technical factors include variables like access to technology, technical support, etc (Nantz \& Lundgren, 1998; Schifter, 2000). Individual factors include the available time that university instructors can 
spend in learning how to use technology, their tolerance of possible failures in using technology, and their beliefs in the effectiveness of technology in enhancing teaching and learning (Adams, 2003; Anderson et al., 1998; Ebersole \& Vorndam, 2003; Hannafin \& Savenye, 1993). Organisational factors, such as a technology strategic plan, administrative support, professional development, and an incentive policy, could influence the adoption of technology (Anderson et al., 1998; Barone \& Hagner, 2001; Green, 1998).

Rogers (2003) argues that individual innovation adoption rates are normally distributed and that adopters can be divided into five groups: Innovators, Early Adopters, Early Majority, Late Majority, and Laggards. There exists a "chasm" between the Early Adopters and the Early Majority. In terms of the adoption of educational technology in higher education, Geoghegan (1994) found that the chasm is so significant that it has stymied almost all efforts to bridge it. This study explores whether the chasm has been surpassed at the studied university after a decade of use and what challenges the university instructors are still facing when they attempted to use computer technology. Among the array of factors, the authors are interested in finding out which factors instructors consider have the greatest influence on their attempts to use technology in their context.

\section{Interplay between technology and pedagogy}

The use of technology is different from the effective use of technology. For example, regarding the use of PowerPoint, Young (2004) stated "some professors simply dump their notes into a PowerPoint presentation and then read them, which can make the delivery even flatter than it would be if the professor did not use slides." Regarding the use of web in teaching and learning, Oliver (2001) described three types of uses: quick dissemination of course information, web enabled supplements, and web engaged activities. Information dissemination refers to the online delivery of course information to students at anytime and anyplace. Web enabled supplements provide students with access to course related materials they would otherwise not have the opportunity to study. Web engaged activities provide students with information processing tools and promote higher order thinking. Studies have found that information dissemination uses of course web pages were far more common than web enabled supplements or interactive activities (Dehoney \& Reeves, 1999). While the limited number of available supplementary materials and web engaged activities may be one reason for this, an important reason comes from an instructor's concept of teaching.

Based on a meta-analysis of thirteen studies of university instructors' conceptions of teaching, Kember (1997) defined five conceptions on a 
continuum from teacher centered to student centered: imparting information, transmitting structured knowledge, student-teacher interaction, facilitating understanding, and conceptual change/intellectual development. An instructor's concept of teaching greatly influences his or her use of technology. However, most university instructors generally do not have an educational background. They do not know how to use technology with pedagogical effectiveness (Zhou, Brouwer, Nocente \& Martin, 2005). As Cuban (2001) noted, a majority of university instructors failed to use the technology available to them and the few who did adopt technology used it primarily to maintain existing classroom practices. Even university instructors who won teaching awards perceive the benefits of teaching a course using $W e b C T$ as pertaining primarily to the convenience and efficiency of course administration and management (Apedoe, Holschuh \& Reeves, 2004). Technology, which may make content delivery more efficient and less expensive, is not necessarily pedagogically advanced (Reeves, 2003; Weigel, 2003). To understand how university instructors use technology, we need to refer to their concept of teaching. Equally true, to enhance university instructors' use of technology, we have to address their teaching philosophy. Therefore, this study searches for answers to such questions as how instructors use technology at the University of Alberta, and how their concepts of teaching interact with their use of technology.

\section{Professional development}

Earlier studies identified the lack of training as one of main barriers to use of computer technology (Denk, Martin \& Sarangarm, 1993; Jacobson \& Weller, 1987). Later studies continue to advocate the importance of professional development for helping university instructors adopt technology (Anderson et al., 1998; Green, 1998). To develop university instructors' familiarity with technology, professional development in the past has been related mainly to technical content, focusing on users' awareness and knowledge of technology (Young, 2004). However, as more and more instructors have started to use technology and become familiar with it, it is time to move professional development into another stage that focuses on the effective use of technology.

This study collects information regarding what experiences, perspectives, and expectations university instructors have for professional development and seeks a solution to promote a wider, more in depth use of technology.

\section{Sample and methods}

All instructors including faculty members and sessional instructors at the University of Alberta were invited to complete an online survey. The 
survey used Likert scale, ranking, yes/no, fill-blank, and open ended questions to assess instructors' concept of teaching and collect information about their use of computer technology. It had 30 questions, but most of them included multiple components. Participants were asked to provide a total of 111 responses. The survey was piloted with a small number of instructors before being administered widely. It took approximately 30 minutes to finish.

Table 1: The structure of the online survey

\begin{tabular}{|c|c|c|}
\hline Section & Question focus & Scale \\
\hline \multirow{4}{*}{$\begin{array}{l}\text { Part } 1 \\
\text { Concept of } \\
\text { teaching }\end{array}$} & $\begin{array}{l}\text { Use of student centered } \\
\text { teaching approaches }\end{array}$ & $\begin{array}{l}\text { Whenever applicable (3), not always when } \\
\text { applicable (2), and never (1) }\end{array}$ \\
\hline & Perspective of teaching & $\begin{array}{l}\text { Rank five statements from } 1 \text { (most } \\
\text { descriptive) to } 5 \text { (least descriptive) based } \\
\text { on the extent to which each statement } \\
\text { describes their perspective of teaching }\end{array}$ \\
\hline & Goals of teaching & $\begin{array}{l}\text { Compare several higher order teaching } \\
\text { goals with teaching subject content using } \\
\text { a Likert scale from much less important } \\
\text { (1) to much more important (5) }\end{array}$ \\
\hline & $\begin{array}{l}\text { Criteria for teaching } \\
\text { success }\end{array}$ & $\begin{array}{l}\text { Not at all important (1) to very important } \\
(5)\end{array}$ \\
\hline \multirow[t]{7}{*}{$\begin{array}{l}\text { Part } 2 \\
\text { Use of } \\
\text { technology }\end{array}$} & $\begin{array}{l}\text { Experience in using } \\
\text { computers }\end{array}$ & $\begin{array}{l}\text { Never (1), less than two years (2), between } \\
\text { two and five years (3), more than five } \\
\text { years (4) }\end{array}$ \\
\hline & $\begin{array}{l}\text { Comfort with the use of } \\
\text { computers }\end{array}$ & $\begin{array}{l}\text { Not at all comfortable (1) to very } \\
\text { comfortable }(5)\end{array}$ \\
\hline & Computer expertise & $\begin{array}{l}\text { None (1), little (2), fair (3), substantial (4), } \\
\text { and extensive (5) }\end{array}$ \\
\hline & Impacts of computers & Strongly disagree (1) to strongly agree (5) \\
\hline & $\begin{array}{l}\text { Motivators to use } \\
\text { computers }\end{array}$ & Strongly disagree (1) to strongly agree (5) \\
\hline & $\begin{array}{l}\text { Barriers to use } \\
\text { computers }\end{array}$ & $\begin{array}{l}\text { Not at all important (1) to very important } \\
(5)\end{array}$ \\
\hline & $\begin{array}{l}\text { Various sources for prof- } \\
\text { essional development }\end{array}$ & $\begin{array}{l}\text { Not at all important (1) to very important } \\
(5)\end{array}$ \\
\hline $\begin{array}{c}\text { Part } 3 \\
\text { Demographics }\end{array}$ & $\begin{array}{l}\text { Gender, age, position, } \\
\text { and subject area }\end{array}$ & Multiple choice \\
\hline
\end{tabular}

The survey consisted of three parts (Table 1). The first part assessed university instructors' concept of teaching from four aspects: use of student centered teaching approaches, perspectives of teaching, goals of teaching, and measurement criteria for teaching success. The second part focused on instructors' current use of computers, expertise in computer technologies, perceived impacts of computers on teaching and learning, factors influencing their use of computers, barriers to the use of computers, experiences and preference in professional development. The third part 
collected demographic information. At the end of the survey, a couple of open ended questions provided participants with an opportunity to give more detailed feedback on any topic covered in the survey.

To triangulate the survey data, five focus groups were conducted with voluntary participants from different Faculties, to collect qualitative information for an in depth understanding of the topics covered in the survey. The average size of focus groups was five participants and each focus group met for slightly over one hour. Five interviews were conducted to gain a deeper understanding of voluntary participants' personal beliefs and practices of teaching and their use of technology. These five interviewees came from Faculties of Science, Business, Medical Science, Agriculture and Education respectively. Each interview lasted about one hour. Focus group discussions and interviews were recorded and transcribed by a research assistant for analysis.

The quantitative survey data were analysed with SPSS software. To simplify the reporting of descriptive data, the five point scale was reduced to three points, that is "strongly disagree" and "disagree" combined into "disagree," and "agree" and "strongly agree" into "agree", with "neutral" not combined, and similarly for other five point scales. The qualitative data obtained from participants' responses to the open ended survey questions, interviews and focus groups were systematically coded and analysed with NVivo software. Participants' comments were categorised into six categories including concept of teaching, perspective on the use of technology, experience in using technology, incentives for the use of technology, barriers to the use of technology, and professional development. Both quantitative and qualitative analyses were validated by at least two researchers.

\section{Results}

A web link for the online survey was sent through an automatic email dispatch program to approximately 2500 email addresses in April 2005. The email list, provided by the Department of Human Resources, included all faculty members (1376), sessional instructors (729), and the remainder were graduate assistants. The cover letter with the survey was addressed to faculty and sessional instructors only, i.e the number of potential respondents was 2105 . The return rate was approximately $16 \%$, with 341 valid responses received.

Participants came from all Faculties on campus. Their demographic data are reported in Table 2 along with the population data, which were obtained from the University Data Books. Male instructors, younger instructors than 35 years old, and associate professors are slightly over- 
represented in the sample. Findings therefore need to be interpreted with caution.

Table 2: Demographic data (sample $\mathrm{n}=341$ and population)

\begin{tabular}{|c|l|c|c|}
\hline \multirow{2}{*}{$\begin{array}{c}\text { Gender } \\
\%\end{array}$} & Demographics & Sample & Population \\
\cline { 2 - 4 } & Female & 56 & 52 \\
\hline \multirow{3}{*}{$\begin{array}{c}\text { Age } \\
\%\end{array}$} & Younger than 35 & 44 & 48 \\
\cline { 2 - 4 } & $36-45$ & 17 & 10 \\
\cline { 2 - 4 } & $46-55$ & 33 & 32 \\
\cline { 2 - 4 } & Older than 55 & 17 & 34 \\
\hline \multirow{3}{*}{$\begin{array}{c}\text { Rank } \\
\%\end{array}$} & Full professor & 29 & 24 \\
\cline { 2 - 4 } & Associate professor & 24 & 33 \\
\cline { 2 - 4 } & Assistant professor & 18 & 14 \\
\cline { 2 - 4 } & Sessional instructor & 29 & 34 \\
\hline
\end{tabular}

\section{Concept of teaching}

Participants were asked to report how frequently they used student centered teaching strategies (Table 3). Approximately $72 \%$ of participants reported to engage students in sharing ideas with neighbors in the classroom whenever possible, $62 \%$ questioned students' ideas before they introduced new concepts or provided solutions, $69 \%$ engaged students in small group work, $65 \%$ encouraged students in small group discussions, $59 \%$ asked students to present their work to the class, and 59\% involved students in hands on activities.

Table 3: The use of student-centered teaching strategies $(\mathrm{n}=341)$

\begin{tabular}{|l|c|c|c|}
\hline \multicolumn{1}{|c|}{ Strategy } & $\begin{array}{c}\text { Never } \\
(\%)\end{array}$ & $\begin{array}{c}\text { Not always when } \\
\text { applicable (\%) }\end{array}$ & $\begin{array}{c}\text { Whenever } \\
\text { applicable (\%) }\end{array}$ \\
\hline $\begin{array}{l}\text { Encourage students to share ideas with } \\
\text { neighbors in classroom }\end{array}$ & 10 & 18 & 72 \\
\hline $\begin{array}{l}\text { Question student ideas before } \\
\text { introducing new concepts }\end{array}$ & 7 & 31 & 62 \\
\hline Engage students in small group work & 13 & 18 & 69 \\
\hline $\begin{array}{l}\text { Engage students in small group } \\
\text { discussion }\end{array}$ & 15 & 20 & 59 \\
\hline Ask students to present their work & 19 & 22 & 59 \\
\hline Use hands on activities & 21 & 20 & \\
\hline
\end{tabular}

Regarding instructors' perspectives on teaching, participants were asked to rate how descriptive each of the following five statements was towards their perspective: (a) I am the subject knowledge authority in the classroom, (b) To teach is to pass on knowledge to students, (c) To teach is to facilitate student learning, (d) My primary job is to explain the subject as clear as possible, and (e) My primary job is to create an environment for 
learning to occur. Statements (a) and (b) represent a teacher centered perspective of teaching, (c) and (e) reflect a student centered perspective, whilst (d) falls between these two perspectives. Participants' number one rank, the most descriptive statement for their perspective of teaching, was selected as an indicator to the estimation of their perspective on teaching. The survey data demonstrate that on this scale approximately $75 \%$ of participants had a student centered teaching perspective, $14 \%$ a teacher centered teaching perspective, and $11 \%$ felt in between.

Participants were asked to compare five different teaching goals with teaching subject content. A solid majority indicated that "develop students' critical thinking skills" and "facilitate student intellectual development" were two more important goals than teaching subject content, with the former goal getting the highest importance. The remaining three goals, namely "relate subject matter to other subjects," "relate subject matter to social issues," and "prepare students for a specific career" were perceived similarly as less important goals compared with teaching subject content. Approximately half of participants viewed "prepare students for a specific career" as the least important goal (Table 4).

Table 4: The importance of five teaching goals relative to teaching subject content $(\mathrm{n}=341)$

\begin{tabular}{|l|c|c|c|}
\hline \multicolumn{1}{|c|}{ Teaching goal } & $\begin{array}{c}\text { Less imp- } \\
\text { ortant (\%) }\end{array}$ & $\begin{array}{c}\text { Just as imp- } \\
\text { ortant (\%) }\end{array}$ & $\begin{array}{c}\text { More imp- } \\
\text { ortant (\%) }\end{array}$ \\
\hline Develop students' critical thinking skills & 2 & 15 & 84 \\
\hline Facilitate student intellectual development & 4 & 20 & 76 \\
\hline Relate subject matter to other subjects & 28 & 37 & 35 \\
\hline Relate subject matter to social issues & 36 & 34 & 30 \\
\hline Prepare students for a specific career & 49 & 23 & 27 \\
\hline
\end{tabular}

Regarding the criteria that the university instructors used to measure their teaching success, two criteria were considered much higher than the others: "students' increased interest in the subject" and "students' active involvement in the course." Coming next was "students' attendance in class." The criterion considered least important was "students' ratings of instruction", followed by "students' marks on exams" (Table 5).

Table 5: Criteria to measure the success of teaching

\begin{tabular}{|l|c|c|c|}
\hline \multicolumn{1}{|c|}{ Criterion } & $\begin{array}{c}\text { Not imp- } \\
\text { ortant (\%) }\end{array}$ & $\begin{array}{c}\text { Somewhat } \\
\text { important (\%) }\end{array}$ & $\begin{array}{c}\text { Important } \\
(\%)\end{array}$ \\
\hline Students' increased interest in the subject & 1 & 7 & 93 \\
\hline Students' active involvement in the course & 1 & 8 & 91 \\
\hline Students' attendance in class & 13 & 27 & 61 \\
\hline Students' marks in exams & 14 & 47 & 39 \\
\hline Students' ratings of instruction & 24 & 39 & 37 \\
\hline
\end{tabular}




\section{Use of computer technology}

The survey asked participants whether they used computer technology in teaching. Approximately $90 \%$ participants reported that they used computer technologies in teaching (computer users) while $10 \%$ did not use computer technologies other than word processing and email tools (non computer users). Approximately 52\% of the computer users had used computers in their teaching careers for more than five years, $36 \%$ between two and five years, and $12 \%$ less than two years. Overall, non users were older than users. About $31 \%$ of non users were over 56 years old while only $13 \%$ of users fell in this age range. In this paper, data about the use of computers will be reported in a comparison format of two groups: users vs. non users.

Participants were asked about how comfortable they were with the use of computers in teaching. Among the computer users group, $78 \%$ felt comfortable, $17 \%$ felt somewhat comfortable, and only $5 \%$ did not feel comfortable. Not surprisingly, non users had a lower comfort level than users. Only $14 \%$ of non users felt comfortable, $26 \%$ felt somewhat comfortable, and $60 \%$ felt uncomfortable.

Table 6: Expertise in computer tools

\begin{tabular}{|c|c|c|c|c|}
\hline \multicolumn{2}{|c|}{ Computer tools } & Little or none (\%) & Fair (\%) & Substantial (\%) \\
\hline \multirow{5}{*}{$\begin{array}{l}\text { Web searching/ } \\
\text { browsing } \\
\text { Presentation package } \\
\text { (PowerPoint) }\end{array}$} & Users & 1 & 12 & 87 \\
\hline & Non users & 6 & 37 & 57 \\
\hline & Users & 5 & 12 & 83 \\
\hline & Non users & 43 & 26 & 31 \\
\hline & Users & 20 & 23 & 57 \\
\hline Spreadsheets & Non users & 66 & 12 & 21 \\
\hline \multirow{2}{*}{$\begin{array}{l}\text { Paint, photo program } \\
\text { (Photoshop, etc) }\end{array}$} & Users & 37 & 24 & 40 \\
\hline & Non users & 77 & 11 & 12 \\
\hline \multirow[t]{2}{*}{ Database } & Users & 36 & 26 & 38 \\
\hline & Non users & 60 & 20 & 20 \\
\hline \multirow{2}{*}{$\begin{array}{l}\text { Webpage creation/ } \\
\text { editing/ publishing }\end{array}$} & Users & 46 & 18 & 35 \\
\hline & Non users & 86 & 9 & 5 \\
\hline \multirow{2}{*}{$\begin{array}{l}\text { LMS (WebCT, } \\
\text { Blackboard, etc) }\end{array}$} & Users & 43 & 25 & 32 \\
\hline & Non users & 80 & 14 & 6 \\
\hline \multirow[t]{2}{*}{ Listservs, news groups } & Users & 49 & 23 & 28 \\
\hline & Non users & 68 & 23 & 9 \\
\hline \multirow[t]{2}{*}{ Discussion Board } & Users & 60 & 16 & 25 \\
\hline & Non users & 74 & 20 & 6 \\
\hline
\end{tabular}

Participants were asked about their expertise in using a variety of computer tools. The computer users reported more expertise than non users for all listed tools (Table 6). A t-test indicated that this difference was statistically significant for every tool $(p<0.000)$. When we examined 
participants' relevant expertise with computer tools, we found that responses from the two groups were similar with only one exception. Both groups reported that they were most familiar with web search and browsing, and presentation package (PowerPoint), followed by spreadsheet, painting or photo programs, database, learning management system (LMS) in that order. Listservers and discussion boards were among the last group of tools that were least familiar to participants. However, the computer users reported their expertise in web page development higher than the last group of tools, while non users set web page development as the thing they were least familiar with.

Of those computer users, approximately $78 \%$ had taught a course with online components and $22 \%$ had not. Those who indicated teaching a course with online components were asked what online tools they had used. The most frequently used tool was "posting syllabus." This was followed by "posting other course documents" such as assignments, supplemental materials, and lecture notes. Then come in order online calendar, online discussion, online quiz or tests, web engaged activities, and, finally, online surveys (Figure 1). It is clear that the interactive tools were reported as being less frequently used than the non-interactive tools.

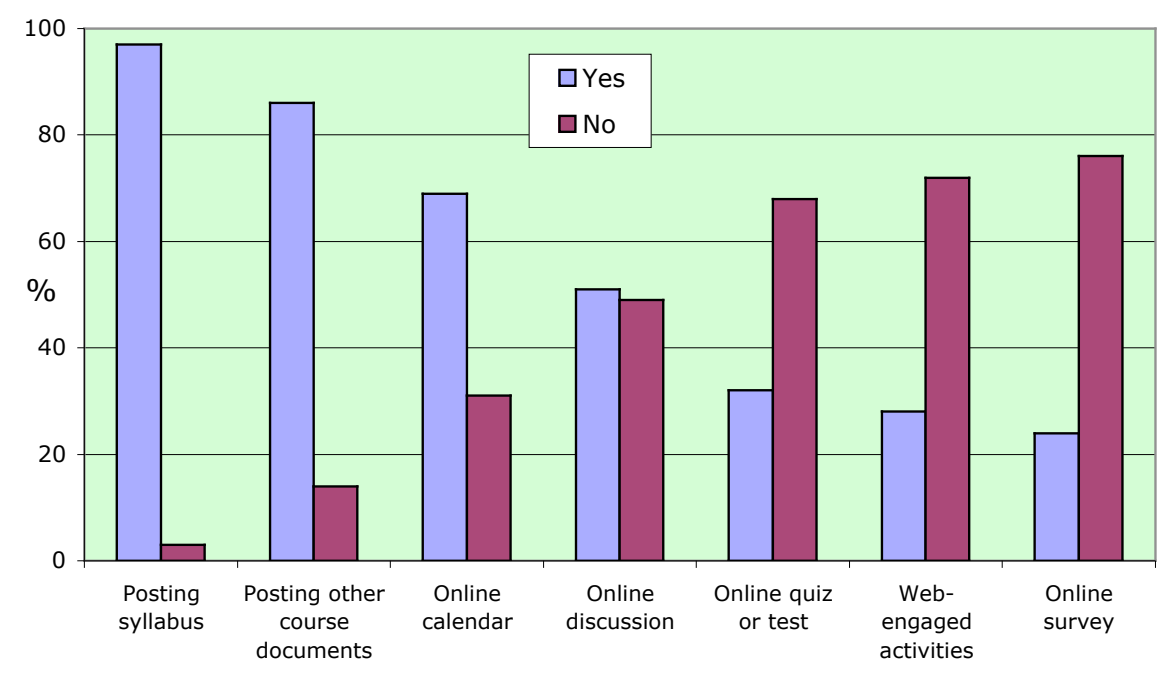

Figure 1: The use of online tools in teaching $(n=341)$

Participants were asked about how they agreed or disagreed with several statements about the impacts of technology on teaching and learning. The computer users tended to agree more with the statements, including "Students communicate better with the instructor and classmates," 
"Students are better able to manage their learning", "Students can learn the material more easily or thoroughly", and "Faculty are better able to present more complex material". The non computer users tended to agree more with statements like "Faculty can spend more time with individual students", "Faculty can spend less time lecturing", and "Faculty can spare time from teaching for research" (Table 7). A t-test showed that statistically significant differences existed between the two groups' responses to two statements. The computer users significantly more agreed with the statement "Students communicate better with the instructor and classmates" as one result of the use of computers than non computer users $(t=2.814, p<0.01)$. The non users significantly more agreed with the statement "Faculty can spend less time lecturing to the entire class" $(t=-$ 2.255, $\mathrm{p}<0.05)$.

Table 7: Impacts of technology on teaching and learning

\begin{tabular}{|c|c|c|c|c|}
\hline \multicolumn{2}{|l|}{ Impact } & $\begin{array}{c}\text { Disagree } \\
(\%)\end{array}$ & $\begin{array}{c}\text { Neutral } \\
(\%)\end{array}$ & $\begin{array}{c}\text { Agree } \\
(\%)\end{array}$ \\
\hline \multirow{2}{*}{$\begin{array}{l}\text { Students communicate better with } \\
\text { the instructor and classmates }\end{array}$} & Users & 12 & 20 & 67 \\
\hline & Non users & 23 & 35 & 42 \\
\hline \multirow{2}{*}{$\begin{array}{l}\text { Students are better able to manage } \\
\text { their learning }\end{array}$} & Users & 12 & 29 & 59 \\
\hline & Non users & 10 & 48 & 42 \\
\hline \multirow{2}{*}{$\begin{array}{l}\text { Students can learn the material } \\
\text { more easily or thoroughly }\end{array}$} & Users & 19 & 28 & 53 \\
\hline & Non users & 27 & 40 & 33 \\
\hline \multirow{2}{*}{$\begin{array}{l}\text { Faculty are better able to present } \\
\text { more complex material }\end{array}$} & Users & 22 & 23 & 54 \\
\hline & Non users & 20 & 35 & 45 \\
\hline \multirow{2}{*}{$\begin{array}{l}\text { Faculty can spend more time with } \\
\text { individual students }\end{array}$} & Users & 39 & 33 & 27 \\
\hline & Non users & 33 & 17 & 50 \\
\hline \multirow{2}{*}{$\begin{array}{l}\text { Faculty can spend less time } \\
\text { lecturing }\end{array}$} & Users & 46 & 25 & 29 \\
\hline & Non users & 24 & 21 & 55 \\
\hline \multirow{2}{*}{$\begin{array}{l}\text { Faculty can spare time from } \\
\text { teaching for research }\end{array}$} & Users & 71 & 19 & 10 \\
\hline & Non users & 59 & 21 & 20 \\
\hline
\end{tabular}

Participants were asked to report their agreement or disagreement with several statements about the incentives or motivators for them to use or plan to use computer technology. A larger percentage of computer users agreed with each statement than non users (Table 8 ). The results of t-tests show that the computer users significantly agreed more with the following statements than non users: "I enjoy figuring out how to use computers in teaching" ( $\mathrm{t}=3.373, \mathrm{p}<0.000)$, "Computers have potentials to enhance teaching and learning" $(\mathrm{t}=2.962, \mathrm{p}<0.01)$, "Students expected instructors to use computers in teaching" $(\mathrm{t}=2.2527, \mathrm{p}<0.05)$, and "Computers provides an environment for different learning styles" $(t=2.306, p<0.05)$. Particularly, over $54 \%$ of computer users reported "I enjoy figuring out how to use computers in teaching" as an important motivator, while less than $30 \%$ of non users took it as an important motivator. Computer users reported this self motivation as a more important motivator than the 
encouragement from university policies, while non users viewed it as the least important motivator. In regard to the relevant importance of motivators, we found that both groups considered the various potentials of computers to enhance teaching and learning as more important motivators than university policies.

Table 8: Incentives for the use of computers in teaching

\begin{tabular}{|c|c|c|c|c|}
\hline \multicolumn{2}{|l|}{ Incentive } & $\begin{array}{c}\text { Disagree } \\
(\%)\end{array}$ & $\begin{array}{c}\text { Neutral } \\
(\%)\end{array}$ & $\begin{array}{c}\text { Agree } \\
(\%)\end{array}$ \\
\hline \multirow{2}{*}{$\begin{array}{l}\text { Computers have potentials to enhance } \\
\text { teaching and learning }\end{array}$} & Users & 3 & 11 & 86 \\
\hline & Non users & 3 & 27 & 70 \\
\hline \multirow{2}{*}{$\begin{array}{l}\text { Computers provide an environment } \\
\text { for different learning styles }\end{array}$} & Users & 8 & 23 & 68 \\
\hline & Non users & 19 & 31 & 50 \\
\hline \multirow{2}{*}{$\begin{array}{l}\text { Computers enable me to make a } \\
\text { subject more interesting }\end{array}$} & Users & 11 & 23 & 66 \\
\hline & Non users & 18 & 24 & 59 \\
\hline \multirow{2}{*}{$\begin{array}{l}\text { Students expect instructors to use } \\
\text { computers in teaching }\end{array}$} & Users & 11 & 26 & 63 \\
\hline & Non users & 24 & 33 & 42 \\
\hline \multirow{2}{*}{$\begin{array}{l}\text { Computers enable students to } \\
\text { collaborate in learning }\end{array}$} & Users & 11 & 33 & 56 \\
\hline & Non users & 21 & 24 & 54 \\
\hline \multirow{2}{*}{$\begin{array}{l}\text { I enjoy figuring out how to use } \\
\text { computers in teaching }\end{array}$} & Users & 27 & 18 & 54 \\
\hline & Non users & 50 & 21 & 29 \\
\hline \multirow{2}{*}{$\begin{array}{l}\text { University policies encourage faculty } \\
\text { to use computers in teaching }\end{array}$} & Users & 25 & 36 & 39 \\
\hline & Non users & 27 & 39 & 33 \\
\hline
\end{tabular}

Regarding the barriers to use computers in teaching, non users tended to consider all barriers greater than did the computer users (Table 9). The $t-$ test results show that this difference is statistically significant $(p<0.05)$ for all barriers except two: "hardware or software is unstable and always breaks down", and "there no recognition from the university or department administration for using computers in teaching." In regard to the relative importance of each barrier, we found that both groups reported "I lack time to develop instruction that uses computers" as the most important barrier. It was followed by "there is no reward from the university or department administration for using computers in teaching" and "there is limited research literature that shows significant improvements in learning as a result of using computers".

The participants who used computers in teaching were asked to evaluate the importance of various sources where they acquired computer skills related to teaching. The source considered as most important was "learning from experience" with $85 \%$ reporting it important, $14 \%$ somewhat important, and only $1 \%$ not important. "Colleague mentoring" was viewed as the third most important resource, coming after "learning from experience" and "support staff assistance," but before "workshops" (Table 10). 
Table 9: Barriers to the use of computers in teaching

\begin{tabular}{|c|c|c|c|c|}
\hline \multicolumn{2}{|l|}{ Barrier } & $\begin{array}{c}\text { Not } \\
\text { important } \\
(\%)\end{array}$ & $\begin{array}{l}\text { Somewhat } \\
\text { important } \\
(\%)\end{array}$ & $\begin{array}{c}\text { Very } \\
\text { important }\end{array}$ \\
\hline \multirow{2}{*}{$\begin{array}{l}\text { Lack of time to develop } \\
\text { instruction that uses computers }\end{array}$} & Users & 18 & 32 & 50 \\
\hline & Non users & 6 & 21 & 73 \\
\hline \multirow{2}{*}{$\begin{array}{l}\text { No reward from administration } \\
\text { for using computers in teaching }\end{array}$} & Users & 34 & 23 & 43 \\
\hline & Non users & 33 & 11 & 56 \\
\hline \multirow{2}{*}{$\begin{array}{l}\text { Limited research literature } \\
\text { convincing the use of computers }\end{array}$} & Users & 55 & 17 & 28 \\
\hline & Non users & 30 & 26 & 44 \\
\hline \multirow[t]{2}{*}{ Unstable hardware or software } & Users & 49 & 24 & 27 \\
\hline & Non users & 38 & 31 & 31 \\
\hline \multirow{2}{*}{$\begin{array}{l}\text { No time in the curriculum for } \\
\text { computer mediated instruction }\end{array}$} & Users & 51 & 24 & 25 \\
\hline & Non users & 23 & 40 & 37 \\
\hline \multirow{2}{*}{$\begin{array}{l}\text { Not many training opportunities } \\
\text { for university instructors }\end{array}$} & Users & 57 & 21 & 22 \\
\hline & Non users & 23 & 43 & 34 \\
\hline \multirow{2}{*}{$\begin{array}{l}\text { Available computer tools don't } \\
\text { fit the course I teach }\end{array}$} & Users & 63 & 20 & 17 \\
\hline & Non users & 32 & 46 & 22 \\
\hline
\end{tabular}

Table 10: Sources for computer users acquiring computer skills for teaching

\begin{tabular}{|l|c|c|c|}
\hline \multicolumn{1}{|c|}{ Source } & $\begin{array}{c}\text { Not imp- } \\
\text { ortant }(\%)\end{array}$ & $\begin{array}{c}\text { Somewhat } \\
\text { important (\%) }\end{array}$ & $\begin{array}{c}\text { Impor- } \\
\text { tant (\%) }\end{array}$ \\
\hline Learning from experience & 1 & 14 & 85 \\
\hline Support staff assistance & 23 & 22 & 55 \\
\hline Colleague mentoring & 25 & 28 & 47 \\
\hline Workshops & 25 & 31 & 44 \\
\hline Formal courses & 36 & 32 & 32 \\
\hline Student assistance & 52 & 24 & 24 \\
\hline Family member assistance & 67 & 13 & 20 \\
\hline
\end{tabular}

The computer users were also asked to reflect on the importance of various sources where they acquired pedagogical knowledge for using computers in teaching. The most important option was again "learning from experience" with $82 \%$ reporting it important, $16 \%$ somewhat important and only $2 \%$ not important. "Colleague mentoring" was reported as the second

Table 11: Sources where computer users gained pedagogical knowledge for using computers

\begin{tabular}{|l|c|c|c|}
\hline \multicolumn{1}{|c|}{ Source } & $\begin{array}{c}\text { Not important } \\
(\%)\end{array}$ & $\begin{array}{c}\text { Somewhat } \\
\text { important (\%) }\end{array}$ & $\begin{array}{c}\text { Important } \\
(\%)\end{array}$ \\
\hline Learning from experience & 2 & 16 & 82 \\
\hline Colleague mentoring & 25 & 29 & 46 \\
\hline Instructional designers & 33 & 21 & 46 \\
\hline Workshops & 25 & 31 & 44 \\
\hline Literature & 41 & 30 & 29 \\
\hline Formal courses & 40 & 33 & 27 \\
\hline
\end{tabular}


most important resource that came after "learning from experience" and before other resources including "workshops" (Table 11).

\section{Concept of teaching versus use of technology}

In order to study the possible relationship between instructors' concept of teaching and use of computers, nine questions about the four studied aspects were selected and clustered into one variable to estimate participants' concept of teaching. Particularly, four selected questions asked participants about how frequently they used the following student centered teaching strategies: "encourage students to share ideas with neighbors in the classroom", "engage students in small group discussion", "question students' ideas before introducing new concepts or providing solutions", and "use hands on activities". Two selected questions asked participants to compare the importance of two high order teaching goals with teaching subject content: "developing students' critical thinking skills" and "facilitate students' intellectual development".

Another two selected questions asked participants about how they considered the importance of two measurement criteria for teaching success: "students' active involvement through the course" and "increased interest in the subject among students". Participants' number one rank, the most descriptive statement for their perspective of teaching, was selected as the ninth contributor to the estimation of their concept of teaching. The participants were scored 1 if they chose "I am the subject knowledge authority in the classroom" or "to teach is to pass on knowledge to students" as the most descriptive statement of their perspective upon teaching. The participants selecting "my primary job is to explain the subject as clearly as possible" as their most descriptive statement were scored 2. The rest who considered "teaching is to facilitate students' learning" or "my primary job is to create an environment for learning to take place" as their most descriptive statements were scored 3.

To make all nine selected questions use the same kind of scale, the five point scales were compressed to three point scales. The clustered measurement of teaching concept therefore has a minimum value of nine and maximum value of twenty seven, with the high number end representing a student centered teaching concept and the low number end a teacher centered teaching concept. If we use a three point scale again for the variable of teaching concept, no participant gets 1 (1-13.4), approximately $25 \%$ of participants get 2 (13.5-22.4), and $75 \%$ get $3(22.5-27)$. That is, approximately three quarters of participants held a student centered concept of teaching. 
A t-test was used to examine whether there were significant differences in concept of teaching between participants who used or did not use (i) computer technology and (ii) online discussion in teaching. The results showed that there was no statistically significant difference between the computer users and non users in their concept of teaching. In other words, the use of computers in teaching was not an indicator for whether a participant had a student centered or teacher centered concept of teaching. However, a statistically significant difference in concept of teaching was detected between participants who used online discussion in teaching and those who did not $(\mathrm{t}=2.055, \mathrm{p}<0.05)$. Among the computer users, those who used online discussion were more likely to have a student centered concept of teaching.

\section{Discussion}

Approximately $90 \%$ of participants reported that they had used computers in their teaching. This number is much higher than the $15 \%$ who claimed to use computers about ten years ago. We therefore conclude that the university may have surpassed the chasm existing between the Early Adopter and Early Majority in the use of computers in teaching. The $10 \%$ who did not use computer technologies other than word processing and email tools in their teaching could be categorised as laggards according to Everett Rogers' diffusion theory (Rogers, 2003). Compared with the participants who used computers in teaching, those participants who didn't were older, had less expertise in various computer tools, and felt less comfortable using computers in teaching. They were less motivated to use computers in teaching and believed less in the impacts of computers in enhancing learning. They also viewed most barriers more significantly. Regarding the sources for acquiring skills and knowledge to use computers in teaching, a majority of participants who used computers in teaching ranked "learning from experience" as their number one source, and they ranked "colleague mentoring" higher than "workshops".

In regard to the interplay between instructors' concept of teaching and their use of technology, this study found that a large percentage of participants reported a student centered concept of teaching. Though scholars often claim that use of computers helps teachers to create a student centered classroom, whether participants did or did not use computers in teaching did not have a direct relationship with their concept of teaching. However, among the participants who used computers in teaching, the concept of teaching was a significant indicator for whether they used computer based, interactive tools such as online discussion in their classes. 
A majority of participants reported using computers in teaching. However, concern arose when we looked into how computers were used in teaching. Over $85 \%$ of participants who claimed to use computers in teaching posted course documents on a course website, but less than $50 \%$ of them used online discussion and web engaged activities. During interviews, participants were asked about why they used technology and what they used it for. Two typical responses were:

The WebCT motivation is primarily a time-saver for me. It's to minimize the number of times that I have to answer the same question. Because I have six hundred students, the number of questions I have that are exactly the same, I tell the students that I post the most frequently asked questions on WebCT [as a document]. So if students send me an email [to ask the same questions], I will say "Your answer's posted" as opposed to writing out the answers for hundreds of times. So it's a time-saver. It's also because students who miss classes will ask me for copies of notes and I don't give copies of notes, so I say the notes are online. It saves me handing things out. I can't give handouts in class very easily so I post handouts online [This interviewee came from the Faculty of Science].

I'm happy to use anything that saves me time and helps me organise materials. That's what technology does [School of Business].

Participants took technology primarily as a time saver rather than a tool for instructional innovations. This raises a question about how to help university instructors expand their use of computers in teaching.

To answer this question, two aspects need to be considered. Firstly, the university needs to modify its reward system so that it will better recognise the effort and scholarship of using computers in teaching. Consistent with the findings from earlier studies (Anderson et al., 1998; Green \& Gilbert, 1995), our study found that participants, be they computer users or non users, viewed the lack of time and lack of reward as the most significant barriers to using computers in teaching. Developing teaching and learning activities that use computers effectively is time consuming. University instructors will not do it continually if their time and effort are not rewarded. The reward may be a favourable count of the use of computers in the process of faculty evaluation and promotion. It may also be in the form of release time, as participants regarded lack of time as the most important barrier.

Secondly, an effective channel needs to be found to deliver to instructors positive evidence and successful cases concerning the use of computers. Our study found that participants from both groups considered the various potentials of computers to enhance teaching and learning as most significant motivators to the use of computers. This finding confirms Jacobsen's statement that the incentives are primarily intrinsic (Jacobsen, 
1998). Unfortunately, many university instructors often lack time and the educational background to explore the potentials that educational technology can bring to teaching.

To make the situation worse, scholarly studies of educational technology are normally published in specific journals that most non-education instructors do not read. Therefore, although there are many evidence based studies and successful cases that support and inform the use of computers in teaching, university instructors are not aware of them. This lack of awareness causes university instructors to question why they need technology (Anderson et al, 1998; Ebersole \& Vorndam, 2003), and wonder how they use technology for pedagogical effectiveness. Similarly, in our study, participants took "there is limited research literature that shows significant improvements in learning" as the third important barrier out of seven. To step out of this dilemma, the easy to access resources coming out of a local academic environment (e.g. a department, a faculty, or even the whole university) could be a solution. This leads us to consider mentorship as a format of professional development.

Professional development plays an important role in the diffusion of any innovation. Over the last decade, professional development in the use of computers has been driven mainly by technical content, which focuses on users' awareness and knowledge of technology. With a majority of instructors possibly having started to use technology, it is time to move professional development to another stage, with a focus on the effective use of technology. The content and format of professional development need to be redirected. During the focus group discussions and interviews, we frequently heard comments from participating instructors on the inadequate information that technical content orientated workshops could provide about how to use computers in teaching their specific subject.

I know how to log on to WebCT, I know how to upload pages. I don't need courses to tell me how to do that. I need discipline-specific questions that need to be answered [Faculty of Science].

The one-off, here's a workshop on PowerPoint or WebCT is not at all effective. People need someone to come to their office, walk them through what it is your doing in your context, here's some tips and tricks, a handout, a phone number that you can call if you need me afterwards. That kind of very integrated and personal type of service. Not more workshops [Faculty of Science].

I think if there's any kind of training, it should be tailored to the specific needs of the discipline and the context that you are [in]... So if somebody were to come and say, "Okay, here's how you can use technology in your Literature or Culture courses", so a way that people who have the expertise in sort of teaching these disciplines and also have the technology, who can bring these things together and give us useful ideas [Faculty of Arts]. 
University instructors wanted to learn strategies of using computers to enhance their subject teaching. They wanted to learn from other instructors whom they had personal relationships with and whom they trusted. This is verified by our survey data which informed us that "colleague mentoring" was considered by participants who used computers in teaching as a more important professional development resource than "workshops." Actually, in some departments, instructors formed informal learning groups to share experiences in using computers.

Somehow people know that I've tried implementing these online quizzes and now everybody, many people, in my department come and ask me WebCT questions [Faculty of Science].

[In my department] there's a lot of mentoring going on that is informal. So for example, there were two faculty members who taught this class for the very first time. They'd never taught very large classes before. They'd never used WebCT. I told them the little that I know. They then had enough information to at least get started in the fall [term] and get the course going. There're a couple of them who have now figured out some more information about how to treat data that comes from online testing. So I went and talked to him about what he learned in the mean time. So it is very question oriented. If you have a question, then you go and ask somebody how you do it. It's not a formal setting where I'm going to come and tell you what I know and I'm going to look to see how you do it. In that sense, people are much more relaxed about it and you learn as much as you need to know [Faculty of Science].

A few participants were acting as unofficial mentors to help other people use computers. They saw their influences on colleagues' attempt to use computers in teaching and recommended that university administrators encourage a mentorship model across campus:

The other suggestion I had around what upper admin could do is that I think that in almost any department, there's a person like me, the gatekeeper, the one who's willing to help people, who becomes that hub. I think if there was the opportunity for a course release for that person to facilitate their helping others, that would be great. Right now I do that on top of my own job because I'm just one of those people. But I think trying to make their lives easier would help to facilitate that process. People have often said, "Well maybe we could send you off to a workshop. You could learn about something and come back and teach us." I say, "Sure, when I'm cloned and I have 48 hours in my day." There are possibilities there but there needs to be money and support behind it [Faculty of Education].

These comments and suggestions convinced us that faculty mentorship should be an important component of future professional development in helping university instructors use computers in teaching. Because peers tend to have similar needs in teaching and can easily understand each 
other's questions and concerns, those instructors who successfully use computers in teaching could be a great source to convince and demonstrate their peers why and how technology is effectively used.

\section{Conclusion}

This study examined technology adoption by university instructors and searched for the best solutions to promote it. The study revealed that instructors' internal motivations play a more important role than external motivations for their attempts to use computers in teaching. Participants took the potentials of computers to enhance teaching as their most important motivator. The participants who used computers learned about how to use computers in teaching more through their experiences than through other sources including workshops, assistance from support staff, training programs and courses. This points us a new direction for future professional development. To encourage instructors to use computers, one important thing that needs to be done is to provide them with a rationale of why computers should be used in classrooms. Evidence and examples that support and demonstrate the effective use of technology should be successfully delivered to instructors. Once intention is built up, university instructors are more willing to try new technology and to take advantage of available resources on campus for their attempts to use computers in teaching. Unfortunately, academic journals are not an effective channel for this purpose. They provide a forum for the researchers in educational technology, but do not influence the majority of instructors.

Mentorship is not a new idea in the literature. However, our study is significant because it provides an evidence based justification and rationale for the use of a mentorship professional development model in technology adoption. Both our quantitative and qualitative data suggest that colleague mentorship can be a welcome way to convince and facilitate instructors to use computers more extensively and effectively. It can, at least theoretically, be an effective alternative channel to deliver to instructors the rationale, evidence, and examples in the use of computers since colleague mentors can provide instructors with easy to access and easy to accept resources. To apply the mentorship model, universities need to identify and create exemplar instructors in each subject area, provide support to their interests and efforts in the use of computers in teaching, purposely put them in the visible spot through showcasing their successes so that other instructors know whom they can consult comfortably about their own attempts to use computers. Of course, like any innovation, the application of mentorship will face many issues such as the fairness of incentives to the mentors, amount of release time, award policies, and efficient and effective use of mentors, etc. To investigate the effectiveness of colleague mentorship for professional development in technology adoption 
and associated implementation issues will be the focus of our future research.

\section{Acknowledgements}

The authors are grateful to the funding support from a Humanities, Fine Arts and Social Sciences Research grant. We also thank Professor Jacobsen at the University of Calgary who kindly permitted us to adapt some questions from a survey instrument she had used previously.

\section{References}

Adams, N. (2003). Educational computing concerns of postsecondary faculty. Journal of Research on Technology in Education, 34(3), 285-303.

Anderson, T., Varnhagen, S. \& Campbell, K. (1998). Faculty adoption of teaching and learning technologies: Contrasting earlier adopters and mainstream faculty. The Canadian Journal of Higher Education, 28(2/3), 71-98.

Apedoe, X., Holschuh, D. \& Reeves, T. (2004). The interplay of teaching conceptions and a course management system among award-wining university professors. Paper presented at the Annual Meeting of the American Educational Research Association, San Diego, USA.

Barone, C. A. \& Hagner, P. R. (Eds.) (2001). Technology-enhanced teaching and learning: Leading and supporting the transformation on our campus. San Francisco: Jossey-Bass.

Cuban, L. (2001). Oversold and underused: Computers in the classroom. Cambridge, MA: Harvard University Press.

Dehoney, J. \& Reeves, T. C. (1999). Instructional and social dimensions of class web pages. Journal of Computing in Higher Education, 10(2), 19-41.

Denk, J., Martin, J. \& Sarangarm, S. (1993). Nor yet comfortable in the classroom: A study of academic computing at three Land-Grant universities. Journal of Educational Technology Systems, 22(1), 39-55.

Ebersole, S. \& Vorndam, M. (2003). Adoption of computer-based instructional methodologies: A case study. International Journal of E-Learning, 2(2), 15-20.

Geoghegan, W. H. (1994). Whatever happened to instructional technology? IBM academic consulting. Paper presented at the 22nd Annual Conference of the International Business Schools Computing Association, July. Baltimore, Maryland.

Green, K. (1998). Colleges struggle with IT planning. The 1998 National Survey of Information Technology in Higher Education. [viewed 10 Sep 2006, verified 6 Oct 2007] http: / / www.campuscomputing.net/summaries / 1998/

Green, K. C. \& Gilbert, S. W. (1995). Academic productivity and technology: Myths, realities, and new necessities. Academe, January/February, 10-25. 
Groves, M. \& Zemel, P (2000). Instructional technology adoption in higher education: An action research case. International Journal of Instructional Media, 27(1), 57-65.

Hannafin, R. D. \& Savenye, W. C. (1993). Technology in the classroom: The teacher's new role and resistance to it. Educational Technology, 33, 26-31.

Jacobsen, D. M. (1998). Adoption patterns and characteristics of faculty who integrate computer technology for teaching and learning in higher education. Unpublished doctoral dissertation. University of Calgary.

Jacobson, M., \& Weller, M. (1987). A profile of computer use among the University of Illinois Humanities faculty. Journal of Educational Technology Systems, 16(2), 8398.

Kember, D. (1997). A reconceptualization of the research into university academics' conceptions of teaching. Learning and Instruction, 7(3), 255-275.

Nantz, K. \& Lundgren, T. D. (1998). Lecturing with technology. College Teaching, 46, 53-56.

Oliver, K. (2001). Recommendations for student tools in online course management systems. Journal of Computing in Higher Education, 13(1), 47-70.

Reeves, T. C. (2003). Storm clouds on the digital education horizon. Journal of Computing in Higher Education, 15(1), 3-26.

Rogers, E. (2003). Diffusion of innovations (5th ed.). NY: Free Press.

Schifter, C. (2000). Faculty participation in asynchronous learning networks: A case study of motivating and inhibiting factors. Journal of Asynchronous Learning Networks, 4(1), 15-22. http:/ / www.sloanc.org/publications/jaln/v4n1/v4n1_schifter.asp

Weigel, V. B. (2003). Deep learning for a digital age: Technology's untapped potential to enrich higher education. San Francisco: Jossey-Bass.

Young, J. R. (2004). When good technology means bad teaching. The Chronicle of Higher Education: Information Technology, 51(12). [viewed 16 Sep 2006, verified 6 Oct 2007]. http:/ / chronicle.com/ free/v51/i12/12a03101.htm

Zhou, G., Brouwer, W., Nocenter, N. \& Martin, B. (2005). Enhancing conceptual learning through computer-based applets: The effectiveness and implications. Journal of Interactive Learning Research, 16(1), 31-49.

Dr George Zhou, Assistant Professor

Faculty of Education, University of Windsor

401 Sunset Ave, Windsor, ON, N9B 3P4, Canada

Email: gzhou@uwindsor.ca

Dr Judy Xu, Technology Coordinator

Department of Physics, University of Alberta

Edmonton, AB, T6G 2G7, Canada

Email: zhijin@ualberta.ca 